Check for updates

Cite this: Mater. Chem. Front., 2019, 3, 1151

\section{A multifunctional AlEgen with high cell-penetrating ability for intracellular fluorescence assays, imaging and drug delivery $\dagger$}

\author{
Yan Jie Li, (D) ${ }^{\text {ab }}$ Hao Tian Zhang, ${ }^{\text {ab }}$ Xiao Ying Chen, ${ }^{a b}$ Peng Fei Gao (D) and \\ Chang-Hua Hu (D) *ab
}

\begin{abstract}
Aggregation-induced emission luminogens (AlEgens) with a definite structure-activity relationship play important roles in site-specific bio-imaging and applications. However, the lack of a clear structureactivity relationship for the excited-state intramolecular proton transfer (ESIPT) molecules, which are a series of powerful AlEgens, restricts their biological applications. Herein, the cell-penetrating capability of 4-N,N-dimethylaminoaniline salicylaldehyde Schiff-bases (DSS) with different substituents was investigated. The diethylamino functionalized ESIPT Schiff base (DSS-4-DEA) displayed high cell-penetrating capacity, making this simple AIEgen turn into a more powerful fluorescent functional material in biosystems. The DSS4-DEA was successfully used for a fluorescence assay of the intracellular $\mathrm{Cu}^{2+}$. Besides, the DSS-4-DEA could also be used as an efficient transmembrane carrier to drastically enhance the internalization of DSS-5-Cl to achieve two-color imaging. In addition, the DSS-4-DEA could be used to improve the transportation of anticancer drug curcumin (Cur) into HeLa cells, leading to increased apoptosis. The complete exploration of the structure-activity relationship of ESIPT molecules might supply lots of new applications of AIE materials in biological systems.
\end{abstract}

Received 10th February 2019, Accepted 13th April 2019

rsc.li/frontiers-materials
DOI: 10.1039/c9qm00089e

\section{Introduction}

Since the aggregation-induced emission (AIE) concept was coined by Tang in $2001,{ }^{1}$ this photophysical phenomenon and the corresponding AIE luminogens (AIEgens) and materials have received extensive attention in various fields, ${ }^{2}$ including optoelectronic systems, ${ }^{3,4}$ biological imaging, ${ }^{5-7}$ sensing, ${ }^{8-10}$ biomedicine, ${ }^{11-14}$ and so on. Compared with the traditional fluorescent dyes with aggregation-caused quenching (ACQ) properties, the AIEgens usually have many advantages in the bio-imaging, such as large Stokes shift, high brightness, excellent photostability and biocompatibility. Besides, AIEgens are always non-emissive in the molecularly dissolved state, but when used in drug delivery systems, the AIEgens can emit intensely in this aggregated state. Obviously, they can play vital roles in tracing the biodistribution and indicating the release of drugs based on the widely used energy transfer.

\footnotetext{
${ }^{a}$ College of Pharmaceutical Sciences, Southwest University, Chongqing 400715, China.E-mail: chhhu@swu.edu.cn

${ }^{b}$ Engineer Research Center of Chongqing Pharmaceutical Process and Quality Control, Chongqing 400715, China

$\dagger$ Electronic supplementary information (ESI) available: Supplementary figures including the optical characterization of the AIEgens, cell-penetrating ability and reason investigation, the response of DSSs to metal ions and the mechanism study etc. See DOI: 10.1039/c9qm00089e
}

As a rising star among the AIEgens, the excited-state intramolecular proton transfer (ESIPT) fluorescent molecules ${ }^{15}$ have recently entered the game of organic solid-state luminescent materials ${ }^{16-20}$ and sensing. ${ }^{21-25}$ The ESIPT molecules usually have several features, which are important for their wide range of applications. Firstly, the ESIPT molecules always display two emission peaks in the fluorescence spectra because of the mutual conversion of their enol- and keto-forms, which is essential for probes with significant change in emission color. $^{21,25}$ Secondly, ESIPT molecules are suitable for $\mathrm{pH}$ sensing based on the protonation and deprotonation of the molecules ${ }^{26}$ or the hydrolysis of the imine bond in the salicylaldehyde Schiff bases. ${ }^{23}$ Besides, in the structure of ESIPT molecules, especially the salicylaldehyde Schiff bases, there is always an efficient coordination site, for example the adjacent imine and hydroxyl, which is important for ESIPT molecular probe-based metal ion sensing..$^{22,27,28}$

ESIPT molecules have proven to be effective fluorescent probes for various analytes and imaging agents both in abiotic systems $^{21,24,29,30}$ and in cells, bacteria and other biological systems. ${ }^{31-35}$ But, until now, only few reports are related to the structure-activity relationship of ESIPT molecules; for example, different membered rings adjust the effectiveness of intramolecular proton transfer in the excited state structure, ${ }^{36}$ and the substituent regulated pH-response. ${ }^{23}$ Compared to the 


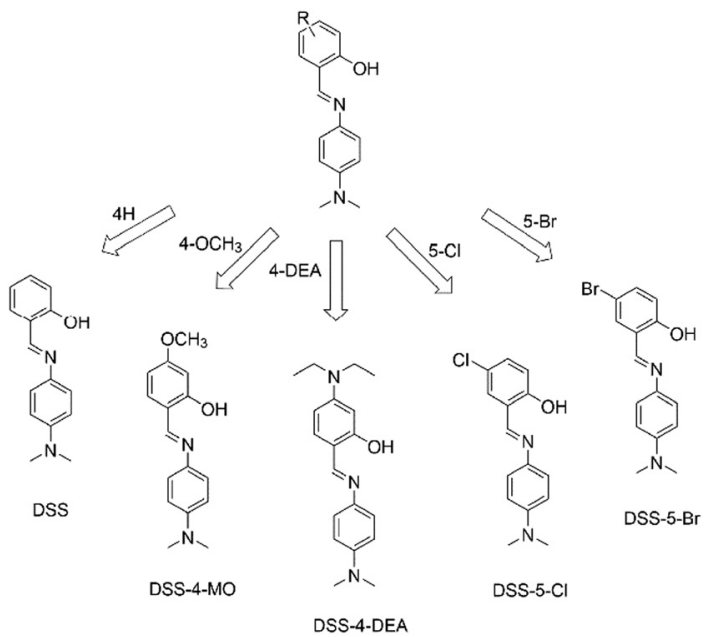

Scheme 1 4-N,N-Dimethylaminoaniline salicylaldehyde Schiff-base (DSS) ESIPT molecules with different substituents.

much clearer structure-cell localization relationships of commonly used AIEgens for bio-imaging and sensing applications, such as the mitochondria targeting ones with cationic and lipophilic characteristics, ${ }^{37-39}$ and the lipid droplet-specific imaging ones with donor-accepter systems and hydrophobicity, ${ }^{40-43}$ the cell substructure specific imaging and penetration performance of ESIPT molecules is indeed important for their biological applications, but rarely researched.

Herein, we chose a series of simple ESIPT molecules with the basic structure of $4-N, N$-dimethylaminoaniline salicylaldehyde Schiff-bases (DSS, Scheme 1), to investigate the substituent regulated cell-penetrating capability. These ESIPT molecules all exhibited AIE or aggregation enhanced emission (AEE) properties. We discovered that the substituents influenced the penetration capacity drastically and the DSS-4-DEA possessed superior penetration capacity to the other four molecules. Combined with its abundant active sites, DSS-4-DEA can be used as a suitable intracellular fluorescent probe for $\mathrm{Cu}^{2+}$, and a useful transmembrane carrier for intracellular molecule transport, such as other AIEgens and drugs with poor cell-penetrating ability. The high cell-penetrating capability of DSS-4-DEA is an important foundation for the multifunction and wide applications of this simple AIE molecular material.

\section{Results and discussion}

The five ESIPT dyes were prepared by one-pot aldimine condensation (see the nuclear magnetic resonance (NMR) characterization results shown in Fig. S1 and S2 (ESI $\dagger$ ), and high resolution mass spectra (HRMS) characterization results shown in Fig. S3, ESI $\dagger$ ). The obvious shoulder peaks on the fluorescence spectra corresponded to the classical enol and keto forms (Fig. 1a, b and Fig. S4, ESI $\dagger$ ). Besides, they all exhibited large Stokes shift up to about $200 \mathrm{~nm}$ (Fig. 1b and Fig. S4, ESI $\dagger$ ). Compared to the fluorescence intensity in pure organic solvents, the DSS and four derivatives all showed enhanced fluorescence
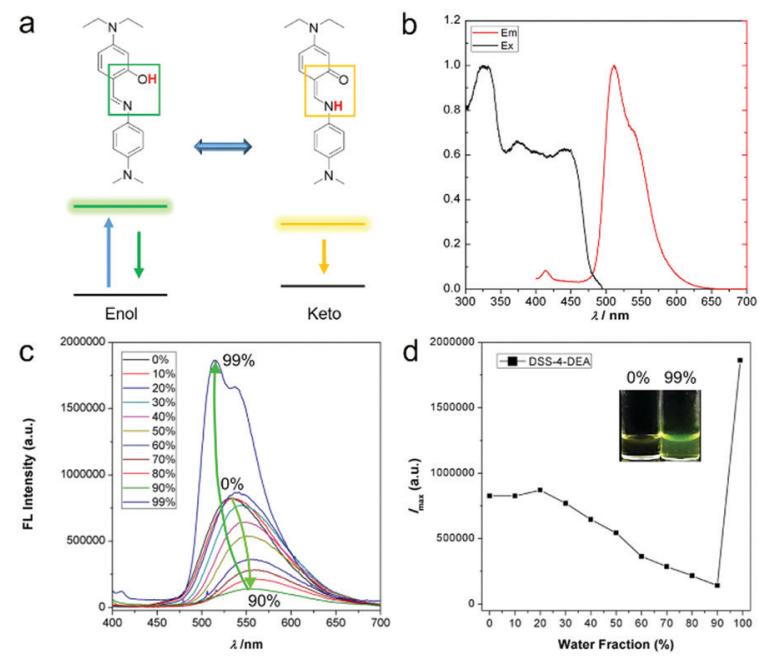

Fig. 1 4-N,N-Dimethylaminoaniline salicylaldehyde Schiff-base (DSS) ESIPT molecules with different substituents.

intensity in high water fractions, so they exhibited AIE or AEE properties. The narrow full width at half maximum (FWHM) of the emission spectra (Fig. 1c, d and Fig. S5, ESI $\dagger$ ) and the good biocompatibility (up to $100 \mu \mathrm{M}$, Fig. S5, ESI $\dagger$ ) were suitable for bio-imaging and related applications. Herein, the firstly red-shift of the emission spectra in Fig. 1c and Fig. S5a and c (ESI $\dagger$ ) was attributed to the enhanced twisted intramolecular charge transfer (TICT) effect along with increased solvent polarity, and the following blue-shift of the emission spectra was attributed to decreased degree of distortion during the aggregation process (as indicated by the arrow in Fig. 1c). This is a classic phenomenon in AIE processes. ${ }^{44}$

The penetration capacity of these dyes in cell imaging was firstly investigated with human cervical cancer (HeLa) cells. The DSS-4-DEA exhibited a high penetration capacity and the HeLa cells could be stained brightly when the concentration of DSS-4-DEA was larger than $25 \mu \mathrm{M}$ (Fig. S9, ESI $\dagger$ ). The penetration capacity of the other four dyes was poor and the cells couldn't be stained with them in $25 \mu \mathrm{M}$ (Fig. 2), except that the cells could be lit up with DSS-5-Br in $100 \mu \mathrm{M}$ (Fig. S7-S11, ESI $\dagger$ ). Three other cell lines, mouse embryonic fibroblast (C3H10 T1/2) cells, human hepatocyte (LO2) cells, mouse macrophage (RAW 264.7) cells were also used to further investigate the penetration capacity of DSS-4-DEA. The results indicated that, at $25 \mu \mathrm{M}$ concentration, the DSS-4-DEA also exhibited better cell-penetrating capacity than the other four derivatives in all the above three cell lines (Fig. S12-S14, ESI $\dagger$ ). Interestingly, the DSS-5-Br also exhibited slightly higher cell-penetrating ability than DSS, DSS-4-MO and DSS-5-Cl.

Although diethylamino has been reported to play interesting roles in the AIE properties and biocompatibility of AIEgens, ${ }^{45,46}$ there is no special functional group in the DSS-4-DEA for specific cell recognition, so the physical and chemical properties might play important roles in the regulation of the penetration capacity. As is well-known, positively charged nanomaterials can always be efficiently internalized due to the negatively 


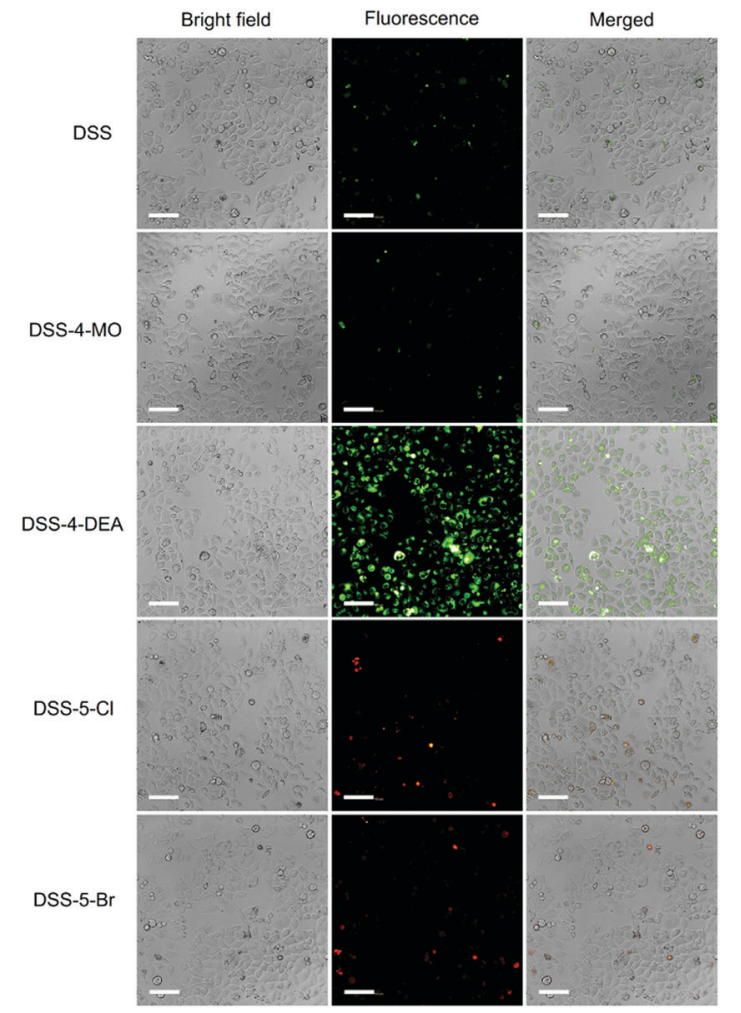

Fig. 2 Fluorescence images of HeLa cells stained with the DSS and the other four derivatives $(25 \mu \mathrm{M})$. Scale bar $100 \mu \mathrm{m}$.

charged cell membrane. ${ }^{47-51}$ So we determined the potential of the aggregates of DSS and four derivatives (DMSO/water, water fraction 99\%), and found that all the five AIEgens showed weak negative charge (mainly between -10 and $0 \mathrm{mV}$, Fig. S15, ESI $\dagger$ ). As a result, the surface charge of the five AIEgens should not be an important reason for the significantly different penetration capacity. Besides, the size of the particles has been reported to have important effects in regulating the cell-penetration and internalization, and particles with a size of about $50 \mathrm{~nm}$ are easy to be internalized; however, when the size increases again, the uptake will be decreased. ${ }^{49,50}$ We measured the size of the aggregates of the five ESIPT dyes in the DMSO/Imaging medium (water fraction 99\%), and found that the sizes of all five ESIPT dyes were small (DSS $80.5 \pm 8.3 \mathrm{~nm}$, DSS-4-MO $123.8 \pm 12.0 \mathrm{~nm}$, DSS-4-DEA $81.6 \pm 8.8 \mathrm{~nm}$, DSS-5-Cl $156.1 \pm 21.5 \mathrm{~nm}$, DSS-5-Br $153.2 \pm 15.9 \mathrm{~nm}$, Fig. S16, ESI $\dagger$ ). There was no obvious correspondence between the size and the cell-penetrating capability.

It has been reported that the cell penetrability of the dyes containing donor-acceptor structures would turn weak with the increased electron-withdrawing ability of the acceptor. ${ }^{40}$ From this perspective, in the five ESIPT dyes, only weak donoracceptor interaction existed in the DSS-5-Cl and DSS-5-Br. The DSS-4-DEA doesn't have an obvious acceptor, so the cell penetrability should not be affected mainly by this factor. The high hydrophobicity or high $\log P$ (n-octanol/water partition coefficient) value has been confirmed to be important in the imaging of lipid droplets. ${ }^{40}$ The calculated $\log P(\operatorname{Cog} P)$ value can be estimated by using ChemBioDraw 14.0. The $\operatorname{Clog} P$ value of
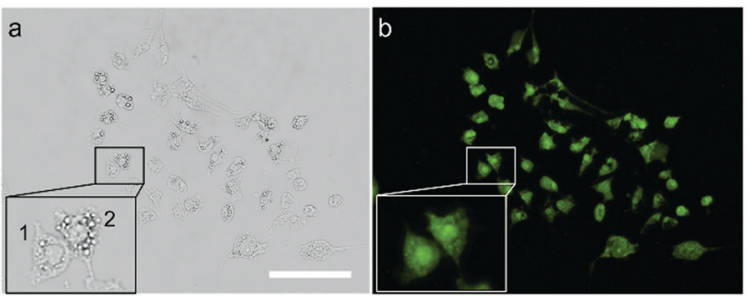

Fig. 3 Fluorescence images of the DSS-4-DEA $(25 \mu \mathrm{M})$ - HeLa cells treated with $0.3 \mathrm{mM}$ sodium oleate and $0.15 \mathrm{mM}$ methyl palmitate, which can induce significant neutral lipids in the cells. (a) Bright field image. (b) Fluorescence image. Cell 1 contains few lipid droplets, and cell 2 contains obvious lipid droplets. Scale bar $50 \mu \mathrm{m}$.

DSS-4-DEA is 4.76, which is the highest. The DSS-5-Br and DSS-5-Cl have a little weak $\operatorname{Clog} P, 4.63$ and 4.36. The $\operatorname{Clog} P$ values of DSS and DSS-4-MO are 3.80 and 3.67. The $\operatorname{Clog} P$ values of the five ESIPT dyes are all below 5, although that of DSS-4-DEA is 4.76. HeLa cells with some lipid droplets were used to investigate whether DSS-4-DEA could stain the lipid droplets. The results showed that the lipid droplets in the cells were not co-located with the fluorescence signal (Fig. 3), and no matter whether the cell had obvious lipid droplets (cell 2) or not (cell 1), the fluorescence signals were nearly the same and showed whole cell distribution. As a result, the DSS-4-DEA was not at the location of lipid droplets to stain the cells. But the $\operatorname{Clog} P$ should play important roles in the penetration capacity. The DSS-5-Br, which had an approximative $\operatorname{Clog} P$ to DSS-4-DEA indeed exhibited a better penetration capacity in a high concentration, $100 \mu \mathrm{M}$ (Fig. S11, ESI $\dagger$ ). And the reduced penetration capacity of DSS-5-Br compared to DSS-4-DEA might be attributed to the weak donor-acceptor interaction. ${ }^{40}$

As the superior cell-penetrating capacity of DSS-4-DEA had been confirmed, next we tried to investigate the stimulusresponse property of DSS-4-DEA. The ESIPT dyes had a coordination site which should be able to react with metal ions. Firstly, the stability of the fluorescence signal of DSS-4-DEA (DMSO/water, water fraction 99\%) was investigated and the results showed that the signal increased in the first two minutes, which could be attributed to the formation process of the stable aggregates. After two minutes, the signal was almost at a steady state (Fig. S17, ESI $\dagger$ ). So the DSS-4-DEA aggregates, after a stabilization of three minutes, were used as the probes. Then, the DSS-4-DEA was screened with fourteen metal ions, and the fluorescence emission was drastically decreased in the case of $\mathrm{Cu}^{2+}$, with $\lambda_{\max }$ at about $515 \mathrm{~nm}$ (Fig. 4a). And the fluorescence quenching was found to occur at small concentrations of $\mathrm{Cu}^{2+}$ (below $10 \mu \mathrm{M}$ ). Then the quenching efficiency of $\mathrm{Cu}^{2+}$ was finely determined, and the results showed that the response concentration range of $\mathrm{Cu}^{2+}$ was $1-10 \mu \mathrm{M}$. When the concentration of $\mathrm{Cu}^{2+}$ was larger than $10 \mu \mathrm{M}$, the fluorescence was almost quenched completely (Fig. 4b). The fluorescence intensity was linearly related and the concentration of the added $\mathrm{Cu}^{2+}$, and the regression equation could be expressed as $\lg F=3845.62-0.46 c_{\mathrm{Cu}^{2+}}\left(R^{2}=0.990\right)$ with a linear range from 1-10 $\mu \mathrm{M}$ (Fig. 4c). And the determined limit of 

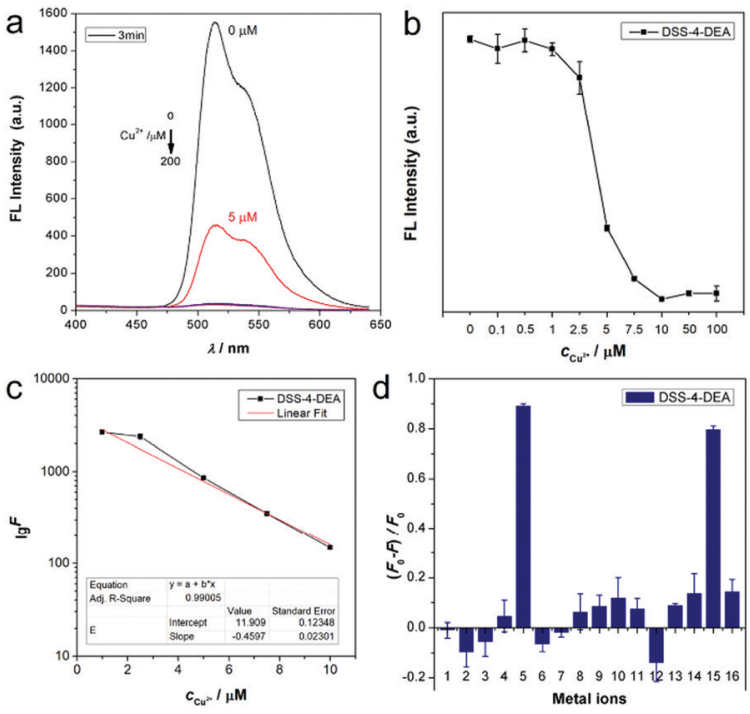

Fig. 4 (a) $\mathrm{Cu}^{2+}(0-200 \mu \mathrm{M})$ induced fluorescence quenching of DSS-4DEA $(100 \mu \mathrm{M})$ after 3 minutes of stabilization. (b) Finely measured $\mathrm{Cu}^{2+}$ (0.1-100 $\mu \mathrm{M}$ ) induced fluorescence quenching of the DSS-4-DEA. (c) Fluorescence intensity against the concentration of $\mathrm{Cu}^{2+}$. (d) Metal ion induced fluorescence quenching of the DSS-4-DEA $\left(1 \mathrm{Ca}^{2+}, 2 \mathrm{Cd}^{2+}\right.$ $3 \mathrm{Co}^{2+}, 4 \mathrm{Cr}^{3+}, 5 \mathrm{Cu}^{2+}, 6 \mathrm{Fe}^{2+}, 7 \mathrm{Fe}^{3+}, 8 \mathrm{~K}^{+}, 9 \mathrm{Mg}^{2+}, 10 \mathrm{Mn}^{2+}, 11 \mathrm{Na}^{+}, 12 \mathrm{Ni}^{2+}$, $13 \mathrm{~Pb}^{2+}, 14 \mathrm{Zn}^{2+}, 15$ all metal ions 1-14, 16 all metal ions 1-14 except $\mathrm{Cu}^{2+}$ ).

detection (LOD) was $0.14 \mu \mathrm{M}(3 \sigma)$. For the other four dyes, the $\mathrm{Cu}^{2+}$ also induced the fluorescence quenching in a similar manner (Fig. 4d and Fig. S18, ESI $\dagger$ ), indicating that $\mathrm{Cu}^{2+}$ should react with the same basic structure in the DSSs. According to the previous reports, the hydroxyl and nitrogen atoms in the imine, which had a suitable spatial distribution, were the binding site. $^{22,52-54}$ The coexisting metal ions didn't quench the fluorescence, but they could coordinate with the DSS structure and compete with $\mathrm{Cu}^{2+}$. This should be the reason for the weakly reduced fluorescence quenching efficiency of the composite metal ions containing $\mathrm{Cu}^{2+}$ compared to $\mathrm{Cu}^{2+}$ alone.

The coordination is usually reversible, so the DSS-4-DEA/ $\mathrm{Cu}^{2+}$ complex may be disintegrated when the stronger chelating agents are added. Disodium ethylenediaminetetraacetate (EDTA-2Na) is a well-known chelating agent, which is usually used as an efficient masking agent to eliminate interference from many metal ions. Herein, we used EDTA-2Na to investigate the fluorescence recovery and to confirm that the mechanism of $\mathrm{Cu}^{2+}$ induced fluorescence quenching was through a coordination mechanism. The EDTA-2Na could react with the $\mathrm{Cu}^{2+}$ quickly, so, after the addition of EDTA-2Na, the fluorescence signal was continuously determined in 20 minutes. Three different EDTA-2Na/ $\mathrm{Cu}^{2+}$ ratios were investigated, and the results showed that when the ratio was up to $10: 1$, the fluorescence could be recovered efficiently (higher than $90 \%$, Fig. 5a, c and Fig. S19, ESI $\dagger$ ).

Besides, the pyrophosphate ion (PPi), another efficient chelating agent for many metal ions, was also used to investigate the fluorescence quenching mechanism. As the coordination capability of PPi was weaker than EDTA-2Na, the fluorescence recovery efficiency was not as high as the EDTA-2Na, even the
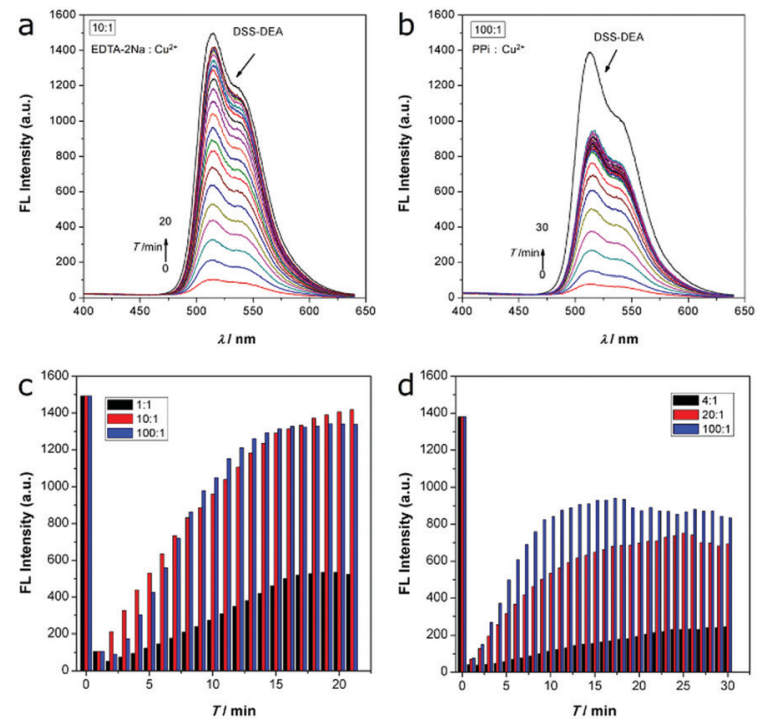

Fig. 5 (a) EDTA-2Na induced fluorescence recovery in 20 minutes (EDTA-2Na: $\mathrm{Cu}^{2+} 10: 1$ ). (b) PPi induced fluorescence recovery in 30 minutes (PPi: $\mathrm{Cu}^{2+} 100: 1$ ). (c) The recovery trend of the EDTA-2Na at different EDTA-2 $\mathrm{Na} / \mathrm{Cu}^{2+}$ ratios induced fluorescence recovery of the DSS-4-DEA/Cu ${ }^{2+}$ complex. (d) The recovery trend of the PPi at different $\mathrm{PPi} / \mathrm{Cu}^{2+}$ ratios induced fluorescence recovery of the DSS-4-DEA/Cu ${ }^{2+}$ complex.

PPi/ $\mathrm{Cu}^{2+}$ ratio was up to $100: 1$ (Fig. 5b, d and Fig. S20, ESI $\dagger$ ). When the PPi/ $/ \mathrm{Cu}^{2+}$ ratio was from $20: 1$ to $100: 1$, the fluorescence recovery ratio only enhanced from about $51 \%$ to about $64 \%$. Although the chelation ability of EDTA-2Na and PPi was significantly different in this system, the similar fluorescence recovery results indicated that the $\mathrm{Cu}^{2+}$ induced fluorescence quenching was mainly through the coordination mechanism.

By taking advantage of the high cell-penetrating capability and the efficient fluorescence response to $\mathrm{Cu}^{2+}$, intracellular fluorescent assay applications of DSS-4-DEA were investigated by imaging of different concentrations of intracellular $\mathrm{Cu}^{2+}$, which is exogenously added. Thirty minutes after the addition of $\mathrm{Cu}^{2+}(1 \mathrm{nM}-100 \mu \mathrm{M})$ into the pre-stained HeLa cells with $25 \mu \mathrm{M}$ DSS-4-DEA, the gradually enhanced quenching of the fluorescence signal was observed and imaged. The obvious fluorescence quenching appeared from $100 \mathrm{nM}$ of $\mathrm{Cu}^{2+}$, and when the concentration of $\mathrm{Cu}^{2+}$ was up to $10 \mu \mathrm{M}$, the fluorescence turned significantly weak (Fig. 6). Because of the reduced DSS-4-DEA concentration used in the intracellular fluorescent assay, and the partially internalized DSS-4-DEA, a lower response concentration of $\mathrm{Cu}^{2+}$ than the spectral analysis, $100 \mathrm{nM}$, was achieved. In addition, a wider response concentration range of the $\mathrm{Cu}^{2+}$ was obtained because of the lower interacting efficiency between the DSS-4-DEA and $\mathrm{Cu}^{2+}$ in the complex intracellular environment. This model of intracellular qualitative imaging analysis applications of DSS-4-DEA displayed the importance of its high cell-penetrating capability for intracellular sensing.

Then, the application of DSS-4-DEA as a transmembrane carrier for improving the cell-penetration of other dyes was investigated. The DSS-5-Cl, which had a poor cell-penetrating capability and red color fluorescence, was chosen as the model cargo. 


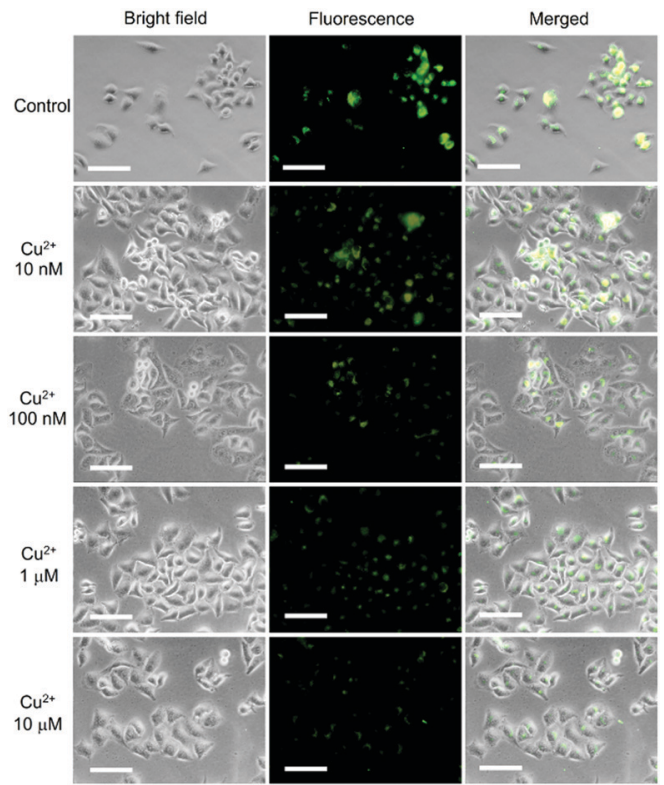

Fig. 6 (a) EDTA-2Na induced fluorescence recovery in 20 minutes (EDTA-2Na: $\mathrm{Cu}^{2+} 10: 1$ ). (b) PPi induced fluorescence recovery in 30 minutes (PPi: $\left.\mathrm{Cu}^{2+} 100: 1\right)$. (c) The recovery trend of the EDTA-2Na at different EDTA-2Na/Cu ${ }^{2+}$ ratios induced fluorescence recovery of the DSS-4-DEA/ $\mathrm{Cu}^{2+}$ complex. (d) The recovery trend of the PPi at different $\mathrm{PPi} / \mathrm{Cu}^{2+}$ ratios induced fluorescence recovery of the DSS-4-DEA/Cu ${ }^{2+}$ complex.

The obvious difference between the fluorescence colors of the DSS-4-DEA and the DSS-5-Cl confirmed the resolution. After the blending with DSS-4-DEA, the DSS-5-Cl showed significantly enhanced internalization. And the co-localized red and green fluorescence suggested that the transport of the intracellular DSS-5-Cl was indeed attributed to the DSS-4-DEA (Fig. 7).

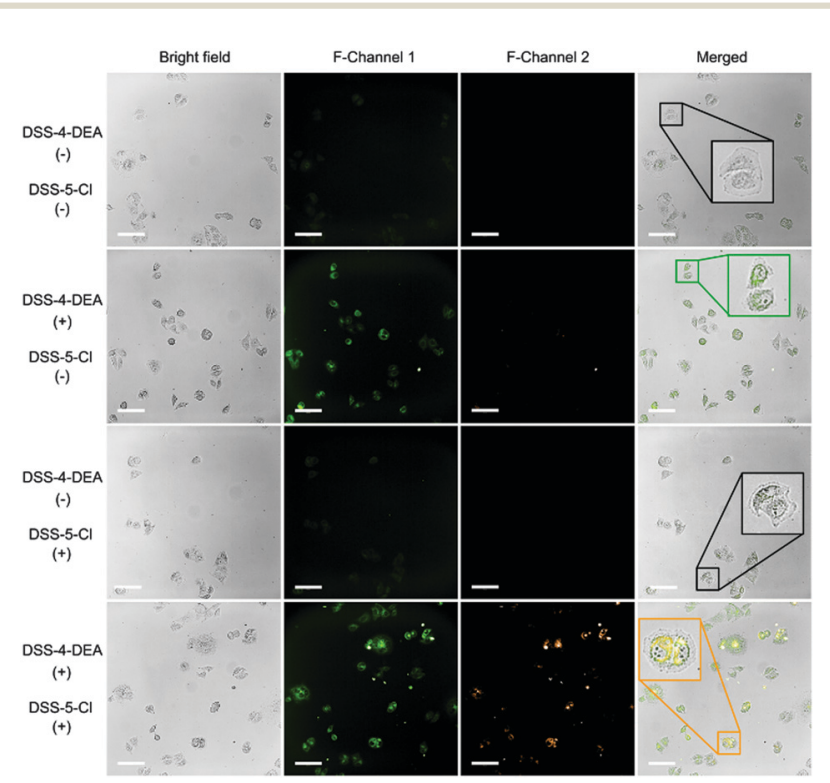

Fig. 7 Fluorescence images of the DSS-4-DEA enhanced intracellular internalization of DSS-5-Cl. Experimental conditions: HeLa cell, $C_{\text {DSS-4-DEA }}$ $50 \mu \mathrm{M}, \mathrm{C}_{\mathrm{DSS}-5-\mathrm{Cl}} 25 \mu \mathrm{M}$, time 30 minutes. Scale bar $50 \mu \mathrm{m}$.
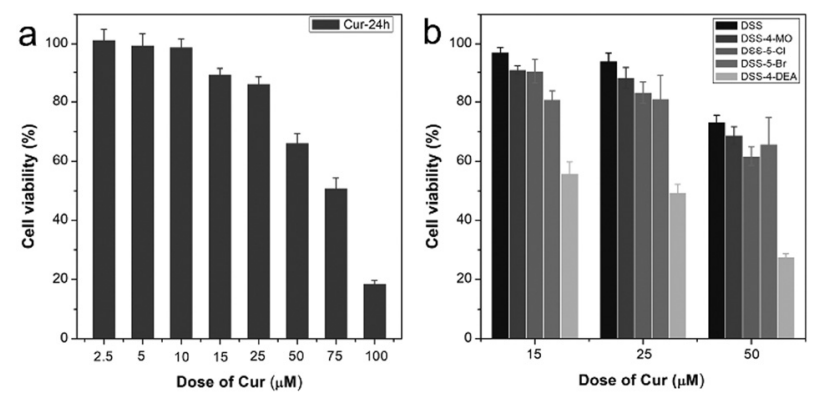

Fig. 8 (a) Cytotoxicity of Cur to HeLa cells. (b) The combined cytotoxicity of DSSs $(50 \mu \mathrm{M})$ with Cur to HeLa cells. All the tested time is $24 \mathrm{~h}$.

These results suggested that, besides the role of the intracellular sensing, the DSS-4-DEA could also be used as a powerful carrier to significantly enhance the cell-penetration of some other fluorescent dyes to achieve multi-color imaging.

Finally, the application of DSS-4-DEA for drug delivery was also investigated. Herein, the anticancer drug curcumin (Cur) was chosen as the model drug. Cur has multiple pharmacologic effects, such as anti-inflammatory, and antiproliferative. However, its poor absorption, rapid metabolism, and rapid systemic elimination always leads to poor bioavailability. ${ }^{55}$ Cur at large concentrations, for example $50 \mu \mathrm{M}$, began to lead to obvious recognizable cytotoxicity to the HeLa cells (Fig. 8a). To improve the anticancer efficiency of Cur, some drug delivery systems have been established, for example, organophilic carbon dots, which can match the hydrophobic nature of Cur well and enhance the transportation of Cur into the cell and accelerate the apoptosis of HeLa cells. ${ }^{56}$ DSS-4-DEA can form aggregates at high water fractions. So the DSS-4-DEA might also be used to load Cur to form complex aggregates. When the Cur $(15,25$ and $50 \mu \mathrm{M})$ and DSS-4-DEA $(50 \mu \mathrm{M})$ worked together, enhanced cytotoxicities were obtained at all three concentrations, although both Cur and DSS-4-DEA showed much lower cytotoxicity alone in these conditions. Besides, the other 4 DSSs didn't bring discernible enhancement to the cytotoxicity of Cur (Fig. 8b). Obviously, the enhanced cytotoxicity was attributed to the DSS-4-EDA and its high cell-penetrating ability. As a result, the simple AIE molecular material, DSS-4-DEA, with high cell-penetrating ability, displayed multiple bio-applications.

\section{Conclusions}

In summary, the effect of substituents on the cell-penetrating capability of AIEgens with ESIPT properties was investigated for the first time. This is an important supplement to the structure-property research category of AIEgens. Interestingly, the diethylamino functionalized ESIPT molecule, DSS-4-DEA, exhibited superior performance in terms of penetration capability than four other analogues, in both HeLa cells and three other cell lines. Combining the fluorescence response to $\mathrm{Cu}^{2+}$, the DSS-4-DEA was successfully used for intracellular fluorescence detection of $\mathrm{Cu}^{2+}$ in a wide linear range. Besides, the DSS-4-DEA could be used to carry other molecules into the 
cells to achieve dual-color imaging. Furthermore, the successfully enhanced cytotoxicity of curcumin suggested the important application of DSS-4-DEA in drug delivery. We expect that this work might motivate scientists to explore the use of AIEgens with specific targeting capability to some subcellular structures, such as the lipid droplets, mitochondria and lysosomes, to carry and delivery drugs precisely. Considering the abundant excellent properties, such as the tunable dual emission, $\mathrm{pH}$-response and strong coordination capability, further exploration of the stable and deterministic cell-penetrating and bio-imaging capability of ESIPT molecular materials is still urgently needed.

\section{Experimental}

\section{Materials}

The following reagents were commercially available and used without further purification. The chemicals for the preparation of the 4-N,N-dimethylaminoaniline salicylaldehyde Schiff-bases (DSS) and four derivatives were obtained from J\&K Chemical Co., Ltd (Beijing, China). The metal salts and curcumin were from Aladdin Chemistry Co., Ltd (Shanghai, China), Chuandong Chemical Reagent Co., Ltd (Chongqing, China) and Kelong Chemical Reagent Co., Ltd (Chengdu, China). Human cervical cancer (HeLa) cells, human hepatocyte (LO2) cells, mouse macrophage (RAW 264.7) cells, and mouse embryonic fibroblast (C3H10 T1/2) cells were obtained from the cell culture center (Institute of Basic Medical Sciences of Chinese Academy of Medical Sciences). All solutions were prepared using ultra-pure water (Millipore, 18.2 M $\Omega$ ).

\section{Apparatus}

${ }^{1} \mathrm{H}$ NMR (400 MHz) and ${ }^{13} \mathrm{C}$ NMR (100 MHz) spectra were recorded on a Bruker Advance DMX 400 spectrophotometer using $\mathrm{CDCl}_{3}$ as a solvent and tetramethylsilane (TMS) as an internal standard. Proton signal multiplicities are given as $\mathrm{s}$ (singlet), d (doublet), t (triplet), q (quartet), and m (multiplet). High resolution mass spectra (HRMS) were recorded on a Bruker impact II10200 mass spectrometer. MTT assay was performed on a Bio-Rad Model 680 microplate reader. Zeta potential measurements were carried out with a Malvern Nano-ZS Zetasizer. The cell-penetrating capability investigation was performed on a PerkinElmer operetta CLS011021 high content analysis system. Fluorescence imaging of intracellular $\mathrm{Cu}^{2+}$ was performed on an Olympus IX-71 fluorescence microscope. Fluorescence spectra were determined on Hitachi F-7000 fluorescence spectrometer.

\section{Preparation of DSS and the four derivatives}

The general synthetic procedure of DSS is as follows. $2 \mathrm{mmol}$ 4 - $N, N$-dimethylaminoaniline and $2 \mathrm{mmol}$ salicylaldehyde were dissolved in $20 \mathrm{~mL}$ of absolute ethanol. The mixture was stirred and heated to $80{ }^{\circ} \mathrm{C}$. $100 \mu \mathrm{L}$ of acetic acid was added as the catalyst. Then, the reaction mixture solution was stirred at $80{ }^{\circ} \mathrm{C}$ for $12 \mathrm{~h}$. The formed precipitates were filtrated and washed with absolute ethanol. The products could be further purified by recrystallization. For the preparation of the other four derivatives of DSS, the salicylaldehyde was replaced by the corresponding salicylaldehyde derivatives.

\section{Cell penetration capability investigation}

Firstly, HeLa cells were used to investigate the penetration capability of the five ESIPT dyes. For each dye, different concentrations $(0-100 \mu \mathrm{M})$ were all used to stain the cell for 30 minutes. Then, the extra dyes were washed with PBS three times before the following high content fluorescence imaging analysis.

For LO2, RAW 264.7, and C3H10 T1/2 cell lines, $25 \mu \mathrm{M}$ of all the five dyes were used to stain the cell. This concentration was chosen from the imaging results of the HeLa cell imaging.

Characterization of the ESIPT dyes

DSS. ${ }^{1} \mathrm{H}$ NMR (400 MHz, $\left.\mathrm{CDCl}_{3}\right) \delta(\mathrm{ppm}) 13.77$ (s, 1H), 8.61 $(\mathrm{s}, 1 \mathrm{H}), 7.38-7.22(\mathrm{~m}, 4 \mathrm{H}), 6.99(\mathrm{~d}, J=8.2 \mathrm{~Hz}, 1 \mathrm{H}), 6.90(\mathrm{t}, J=$ $7.5 \mathrm{~Hz}, 1 \mathrm{H}), 6.74(\mathrm{~d}, J=9.0 \mathrm{~Hz}, 2 \mathrm{H}), 2.99(\mathrm{~s}, 6 \mathrm{H}) .{ }^{13} \mathrm{C} \mathrm{NMR}$ $\left(100 \mathrm{MHz}, \mathrm{CDCl}_{3}\right) \delta(\mathrm{ppm}) 160.91,157.64,149.91,137.09$, 132.03, 131.53, 122.20, 119.77, 118.83, 117.04, 112.76, 40.63. HRMS (EI): calculated for $\mathrm{C}_{15} \mathrm{H}_{17} \mathrm{~N}_{2} \mathrm{O}:[\mathrm{M}+\mathrm{H}]^{+} 241.1335$, found 241.1333 .

DSS-4-MO. ${ }^{1} \mathrm{H}$ NMR (400 MHz, $\left.\mathrm{CDCl}_{3}\right) \delta(\mathrm{ppm}) 14.30(\mathrm{~s}, 1 \mathrm{H})$, 8.51 (s, 1H), 7.29-7.19 (m, 3H), 6.80-6.71 (m, 2H), 6.52-6.42 (m, 2H), 3.84 (s, 3H), 2.98 (s, 6H). $\left.{ }^{13} \mathrm{C} \mathrm{NMR} \mathrm{(100} \mathrm{MHz,} \mathrm{CDCl}_{3}\right) \delta$ (ppm) 163.95, 163.26, 157.10, 149.56, 137.06, 132.78, 121.82, 113.52, 112.91, 106.68, 101.14, 55.42, 40.70. HRMS (EI): calculated for $\mathrm{C}_{16} \mathrm{H}_{19} \mathrm{~N}_{2} \mathrm{O}_{2}$ : $[\mathrm{M}+\mathrm{H}]^{+}$271.1441, found 271.1431.

DSS-4-DEA. ${ }^{1} \mathrm{H}$ NMR (400 MHz, $\left.\mathrm{CDCl}_{3}\right) \delta(\mathrm{ppm}) 14.23(\mathrm{~s}, 1 \mathrm{H})$, $8.39(\mathrm{~s}, 1 \mathrm{H}), 7.23-7.16(\mathrm{~m}, 2 \mathrm{H}), 7.12(\mathrm{~d}, J=8.7 \mathrm{~Hz}, 1 \mathrm{H}), 6.78-6.71$ $(\mathrm{m}, 2 \mathrm{H}), 6.26-6.15(\mathrm{~m}, 2 \mathrm{H}), 3.39(\mathrm{q}, J=7.1 \mathrm{~Hz}, 4 \mathrm{H}), 2.96(\mathrm{~s}, 6 \mathrm{H})$, $1.20(\mathrm{t}, J=7.1 \mathrm{~Hz}, 6 \mathrm{H}) .{ }^{13} \mathrm{C} \mathrm{NMR}\left(100 \mathrm{MHz}, \mathrm{CDCl}_{3}\right) \delta(\mathrm{ppm})$ 164.26, 156.96, 151.25, 149.02, 137.96, 133.05, 121.44, 113.18, 109.44, 103.44, 98.05, 44.55, 40.86, 12.76. HRMS (EI): calculated for $\mathrm{C}_{19} \mathrm{H}_{26} \mathrm{~N}_{3} \mathrm{O}$ : $[\mathrm{M}+\mathrm{H}]^{+}$312.2070, found 312.2070.

DSS-5-Cl. ${ }^{1} \mathrm{H}$ NMR (400 MHz, $\left.\mathrm{CDCl}_{3}\right) \delta(\mathrm{ppm}) 13.76(\mathrm{~s}, 1 \mathrm{H})$, $8.50(\mathrm{~s}, 1 \mathrm{H}), 7.31-7.17(\mathrm{~m}, 4 \mathrm{H}), 6.90(\mathrm{~d}, J=8.8 \mathrm{~Hz}, 1 \mathrm{H}), 6.74-6.67$ $(\mathrm{m}, 2 \mathrm{H}), 2.98(\mathrm{~s}, 6 \mathrm{H}) .{ }^{13} \mathrm{C} \mathrm{NMR}\left(100 \mathrm{MHz}, \mathrm{CDCl}_{3}\right) \delta(\mathrm{ppm})$ 159.44, 155.79, 150.18, 136.34, 131.66, 130.47, 123.35, 122.33, 120.59, 118.54, 112.64, 40.54. HRMS (EI): calculated for $\mathrm{C}_{15} \mathrm{H}_{16} \mathrm{ClN}_{2} \mathrm{O}:[\mathrm{M}+\mathrm{H}]^{+}$275.0946, found 275.0955.

DSS-5-Br. ${ }^{1} \mathrm{H}$ NMR (400 MHz, $\left.\mathrm{CDCl}_{3}\right) \delta(\mathrm{ppm}) 13.79(\mathrm{~s}, 1 \mathrm{H})$, $8.50(\mathrm{~s}, 1 \mathrm{H}), 7.43(\mathrm{~d}, J=2.4 \mathrm{~Hz}, 1 \mathrm{H}), 7.34(\mathrm{dd}, J=8.8,2.5 \mathrm{~Hz}, 1 \mathrm{H})$, $7.28-7.21(\mathrm{~m}, 2 \mathrm{H}), 6.86(\mathrm{~d}, J=8.8 \mathrm{~Hz}, 1 \mathrm{H}), 6.75-6.67(\mathrm{~m}, 2 \mathrm{H})$, $2.98(\mathrm{~s}, 6 \mathrm{H}) .{ }^{13} \mathrm{C}$ NMR $\left(100 \mathrm{MHz}, \mathrm{CDCl}_{3}\right) \delta$ (ppm) 159.91, 155.66, 150.18, 136.30, 134.46, 133.45, 122.33, 121.23, 118.99, 112.64, 110.25, 40.54. HRMS (EI): calculated for $\mathrm{C}_{15} \mathrm{H}_{16} \mathrm{BrN}_{2} \mathrm{O}:[\mathrm{M}+\mathrm{H}]^{+}$ 319.0441 , found 319.0451 .

\section{Fluorescent assay of $\mathrm{Cu}^{2+}$ and the selectivity}

Before the investigation, the fluorescence stability of the DSS-4DEA was firstly monitored. Then, DSS-4-DEA aggregates formed after 3 minutes were chosen as the probes. Different concentrations 
of $\mathrm{Cu}^{2+}$ were added to the formed DSS-4-DEA aggregates $(100 \mu \mathrm{M}$, pH 7.4 PB buffer). After 20 minutes, the fluorescence spectra were measured.

Fourteen metal ions were used to investigate the fluorescence quenching efficiency of DSS-4-DEA $\left(1 \mathrm{Ca}^{2+}, 2 \mathrm{Cd}^{2+}, 3 \mathrm{Co}^{2+}\right.$, $4 \mathrm{Cr}^{3+}, 5 \mathrm{Cu}^{2+}, 6 \mathrm{Fe}^{2+}, 7 \mathrm{Fe}^{3+}, 8 \mathrm{~K}^{+}, 9 \mathrm{Mg}^{2+}, 10 \mathrm{Mn}^{2+}, 11 \mathrm{Na}^{+}$, $12 \mathrm{Ni}^{2+}, 13 \mathrm{~Pb}^{2+}, 14 \mathrm{Zn}^{2+}, 15$ all metal ions 1-14, 16 all metal ions 1-14 except $\mathrm{Cu}^{2+}$ ). The sixteen groups of experiments were also used to confirm whether the $\mathrm{Cu}^{2+}$ induced fluorescence quenching was a common phenomenon for all five ESIPT dyes.

\section{EDTA-2Na and PPi induced fluorescence recovery}

$100 \mu \mathrm{M}$ DSS-4-DEA and $10 \mu \mathrm{M} \mathrm{Cu}^{2+}$ were firstly mixed to form a complex, which showed no obvious fluorescence. Then, three concentrations of EDTA-2Na were added to the complex respectively. The EDTA-2Na/Cu ${ }^{2+}$ ratios were $1: 1,10: 1$ and 100:1. As the coordination capability of EDTA-2Na was strong, the fluorescence spectra were monitored for 20 minutes. For PPi, due to the weak coordination capability, the $\mathrm{PPi} / \mathrm{Cu}^{2+}$ ratios were $4: 1,20: 1$ and $100: 1$. And the fluorescence spectra were monitored for 30 minutes.

\section{Intracellular fluorescence assay of $\mathrm{Cu}^{2+}$}

Firstly, HeLa cells were stained with $25 \mu \mathrm{M}$ of DSS-4-DEA for 30 minutes. The extra DSS-4-DEA was washed with PBS. Then, different concentrations of $\mathrm{Cu}^{2+}(0-100 \mu \mathrm{M})$ were added and incubated for 30 minutes. The cells were imaged by an Olympus IX-71 fluorescence microscope with $20 \times$ objective lens.

\section{DSS-4-DEA enhanced intracellular internalization}

HeLa cells were stained with four groups of dyes 1 control, 2 DSS-4-DEA $50 \mu \mathrm{M}, 3$ DSS-5-Cl $25 \mu \mathrm{M}, 4$ DSS-4-DEA $50 \mu \mathrm{M}$ and DSS-5-Cl $25 \mu \mathrm{M}$ ) for 30 minutes. After the extra dyes were washed with PBS three times, high content fluorescence imaging analysis was performed.

\section{DSS-4-DEA enhanced cytotoxicity of Cur}

Firstly, the cytotoxicity of different concentrations of Cur $(0-100 \mu \mathrm{M})$ to HeLa cells was tested. And the cell viability was obtained by comparison to the control. Then, 15, 25 and $50 \mu \mathrm{M}$ Cur were selected to investigate the DSS-4-DEA enhanced cytotoxicity. For all three groups, $50 \mu \mathrm{M}$ DSS-4-DEA was used as the carrier. Simultaneously, $50 \mu \mathrm{M}$ of the four other DSSs were also used to confirm that the DSS-4-DEA with high cell-penetrating ability was indispensable. After staining with MTT at $37^{\circ} \mathrm{C}$ for $4 \mathrm{~h}$, the culture medium was removed, and $150 \mu \mathrm{L}$ DMSO per well was added. Cell viability was assayed by measuring the absorbance at $490 \mathrm{~nm}$ with a microplate reader.

\section{Conflicts of interest}

The authors declare that they have no conflict of interest.

\section{Acknowledgements}

This work was supported by Chongqing Science and Technology Innovation Special Project for Social Livelihood (No. cstc2016shmszx80102) and the National Key Research and Development Program of China for Traditional Chinese Medicine Modernization (2017YFC1702601).

\section{Notes and references}

1 J. Luo, Z. Xie, J. W. Y. Lam, L. Cheng, H. Chen, C. Qiu, H. S. Kwok, X. Zhan, Y. Liu, D. Zhu and B. Z. Tang, Chem. Commun., 2001, 1740-1741, DOI: 10.1039/B105159H.

2 J. Mei, N. L. C. Leung, R. T. K. Kwok, J. W. Y. Lam and B. Z. Tang, Chem. Rev., 2015, 115, 11718-11940.

3 J. Huang, H. Nie, J. Zeng, Z. Zhuang, S. Gan, Y. Cai, J. Guo, S.-J. Su, Z. Zhao and B. Z. Tang, Angew. Chem., Int. Ed., 2017, 56, 12971-12976.

4 L. Chen, G. Lin, H. Peng, S. Ding, W. Luo, R. Hu, S. Chen, F. Huang, A. Qin, Z. Zhao and B. Z. Tang, Mater. Chem. Front., 2017, 1, 176-180.

5 Z. Zhao, H. Su, P. Zhang, Y. Cai, R. T. K. Kwok, Y. Chen, Z. He, X. Gu, X. He, H. H. Y. Sung, I. D. Willimas, J. W. Y. Lam, Z. Zhang and B. Z. Tang, J. Mater. Chem. B, 2017, 5, 1650-1657.

6 X. He, Z. Zhao, L.-H. Xiong, P. F. Gao, C. Peng, R. S. Li, Y. Xiong, Z. Li, H. H. Y. Sung, I. D. Williams, R. T. K. Kwok, J. W. Y. Lam, C. Z. Huang, N. Ma and B. Z. Tang, J. Am. Chem. Soc., 2018, 140, 6904-6911.

7 Y.-L. Wang, C. Fan, B. Xin, J.-P. Zhang, T. Luo, Z.-Q. Chen, Q.-Y. Zhou, Q. Yu, X.-N. Li, Z.-L. Huang, C. Li, M.-Q. Zhu and B. Z. Tang, Mater. Chem. Front., 2018, 2, 1554-1562.

8 R. T. K. Kwok, C. W. T. Leung, J. W. Y. Lam and B. Z. Tang, Chem. Soc. Rev., 2015, 44, 4228-4238.

9 L.-H. Xiong, X. He, Z. Zhao, R. T. K. Kwok, Y. Xiong, P. F. Gao, F. Yang, Y. Huang, H. H. Y. Sung, I. D. Williams, J. W. Y. Lam, J. Cheng, R. Zhang and B. Z. Tang, ACS Nano, 2018, 12, 9549-9557.

10 Y. He, Y. Li, H. Su, Y. Si, Y. Liu, Q. Peng, J. He, H. Hou and K. Li, Mater. Chem. Front., 2019, 3, 50-56.

11 C. Zhu, R. T. K. Kwok, J. W. Y. Lam and B. Z. Tang, ACS Appl. Bio Mater., 2018, 1, 1768-1786.

12 Y. Yuan and B. Liu, Chem. Sci., 2017, 8, 2537-2546.

13 L. Wang, W. Wang and Z. Xie, J. Mater. Chem. B, 2016, 4, 4263-4266.

14 C. Chen, Z. Song, X. Zheng, Z. He, B. Liu, X. Huang, D. Kong, D. Ding and B. Z. Tang, Chem. Sci., 2017, 8, 2191-2198.

15 J. Seo, S. Kim and S. Y. Park, J. Am. Chem. Soc., 2004, 126, 11154-11155.

16 T. Mutai, H. Tomoda, T. Ohkawa, Y. Yabe and K. Araki, Angew. Chem., Int. Ed., 2008, 47, 9522-9524.

17 K.-C. Tang, M.-J. Chang, T.-Y. Lin, H.-A. Pan, T.-C. Fang, K.-Y. Chen, W.-Y. Hung, Y.-H. Hsu and P.-T. Chou, J. Am. Chem. Soc., 2011, 133, 17738-17745.

18 L. Huapeng, L. Zhuoqun, Z. Zuolun, W. Yue and Z. Hongyu, Angew. Chem., Int. Ed., 2018, 57, 8448-8452. 
19 B. Li, L. Zhou, H. Cheng, Q. Huang, J. Lan, L. Zhou and J. You, Chem. Sci., 2018, 9, 1213-1220.

20 L. Wang, Y. Li, X. You, K. Xu, Q. Feng, J. Wang, Y. Liu, K. Li and H. Hou, J. Mater. Chem. C, 2017, 5, 65-72.

21 H. Wen, Q. Huang, X.-F. Yang and H. Li, Chem. Commun., 2013, 49, 4956-4958.

22 Y.-Z. Xie, G.-G. Shan, P. Li, Z.-Y. Zhou and Z.-M. Su, Dyes Pigm., 2013, 96, 467-474.

23 Q. Feng, Y. Li, L. Wang, C. Li, J. Wang, Y. Liu, K. Li and H. Hou, Chem. Commun., 2016, 52, 3123-3126.

24 M. Gao, S. Li, Y. Lin, Y. Geng, X. Ling, L. Wang, A. Qin and B. Z. Tang, ACS Sens., 2016, 1, 179-184.

25 Q. Feng, Y. Li, K. Li, J. Lu, J. Wang, P. Fan, D. Li, D. Wu and H. Hou, ChemistrySelect, 2017, 2, 3158-3162.

26 V. Kachwal, I. S. Vamsi Krishna, L. Fageria, J. Chaudhary, R. Kinkar Roy, R. Chowdhury and I. R. Laskar, Analyst, 2018, 143, 3741-3748.

27 Y.-J. Bian, L.-Q. Wang, F.-X. Cao and L.-J. Tang, J. Fluoresc., 2016, 26, 53-57.

28 G. Kumar, K. Paul and V. Luxami, Sens. Actuators, B, 2018, 263, 585-593.

29 L. Chen, H. Oh, D. Wu, M. H. Kim and J. Yoon, Chem. Commun., 2018, 54, 2276-2279.

30 G. Jiang, W. Zhu, Q. Chen, X. Li, G. Zhang, Y. Li, X. Fan and J. Wang, Sens. Actuators, B, 2018, 261, 602-607.

31 Y. Liu, J. Nie, J. Niu, W. Wang and W. Lin, J. Mater. Chem. B, 2018, 6, 1973-1983.

32 L. Wu, Y. Wang, M. Weber, L. Liu, A. C. Sedgwick, S. D. Bull, C. Huang and T. D. James, Chem. Commun., 2018, 54, 9953-9956.

33 D. Dahal, K. R. Ojha, N. Alexander, M. Konopka and Y. Pang, Sens. Actuators, B, 2018, 259, 44-49.

34 G. Jiang, J. Wang, Y. Yang, G. Zhang, Y. Liu, H. Lin, G. Zhang, Y. Li and X. Fan, Biosens. Bioelectron., 2016, 85, 62-67.

35 G. Jiang, X. Liu, Q. Chen, G. Zeng, Y. Wu, X. Dong, G. Zhang, Y. Li, X. Fan and J. Wang, Sens. Actuators, B, 2017, 252, $712-716$.

36 X. Qin, G. Ding, Z. Wang, Y. Gong, F. Gao, S. Zhang, Z. Luo and H. Li, Tetrahedron, 2017, 73, 403-410.

37 Z. Zheng, T. Zhang, H. Liu, Y. Chen, R. T. K. Kwok, C. Ma, P. Zhang, H. H. Y. Sung, I. D. Williams, J. W. Y. Lam, K. S. Wong and B. Z. Tang, ACS Nano, 2018, 12, 8145-8159.

38 C. Y. Y. Yu, W. Zhang, R. T. K. Kwok, C. W. T. Leung, J. W. Y. Lam and B. Z. Tang, J. Mater. Chem. B, 2016, 4, 2614-2619.
39 M. Jiang, X. Gu, R. T. K. Kwok, Y. Li, H. H. Y. Sung, X. Zheng, Y. Zhang, J. W. Y. Lam, I. D. Williams, X. Huang, K. S. Wong and B. Z. Tang, Adv. Funct. Mater., 2018, 28, 1704589.

40 G. Niu, R. Zhang, J. P. C. Kwong, J. W. Y. Lam, C. Chen, J. Wang, Y. Chen, X. Feng, R. T. K. Kwok, H. H. Y. Sung, I. D. Williams, M. R. J. Elsegood, J. Qu, C. Ma, K. S. Wong, X. Yu and B. Z. Tang, Chem. Mater., 2018, 30, 4778-4787.

41 M. Jiang, X. Gu, J. W. Y. Lam, Y. Zhang, R. T. K. Kwok, K. S. Wong and B. Z. Tang, Chem. Sci., 2017, 8, 5440-5446.

42 M. Gao, H. Su, Y. Lin, X. Ling, S. Li, A. Qin and B. Z. Tang, Chem. Sci., 2017, 8, 1763-1768.

43 D. Wang, H. Su, R. T. K. Kwok, G. Shan, A. C. S. Leung, M. M. S. Lee, H. H. Y. Sung, I. D. Williams, J. W. Y. Lam and B. Z. Tang, Adv. Funct. Mater., 2017, 27, 1704039.

44 R. Hu, E. Lager, A. Aguilar-Aguilar, J. Liu, J. W. Y. Lam, H. H. Y. Sung, I. D. Williams, Y. Zhong, K. S. Wong, E. PeñaCabrera and B. Z. Tang, J. Phys. Chem. C, 2009, 113, 15845-15853.

45 L. Peng, S. Xu, X. Zheng, X. Cheng, R. Zhang, J. Liu, B. Liu and A. Tong, Anal. Chem., 2017, 89, 3162-3168.

46 Y. Lin, G. Chen, L. Zhao, W. Z. Yuan, Y. Zhang and B. Z. Tang, J. Mater. Chem. C, 2015, 3, 112-120.

47 J. Mosquera, M. Henriksen-Lacey, I. García, M. MartínezCalvo, J. Rodríguez, J. L. Mascareñas and L. M. Liz-Marzán, J. Am. Chem. Soc., 2018, 140, 4469-4472.

48 A. Verma and F. Stellacci, Small, 2010, 6, 12-21.

49 Y. Jiang, S. Huo, T. Mizuhara, R. Das, Y.-W. Lee, S. Hou, D. F. Moyano, B. Duncan, X.-J. Liang and V. M. Rotello, ACS Nano, 2015, 9, 9986-9993.

50 B. D. Chithrani, A. A. Ghazani and W. C. W. Chan, Nano Lett., 2006, 6, 662-668.

51 E. C. Cho, J. Xie, P. A. Wurm and Y. Xia, Nano Lett., 2009, 9, 1080-1084.

52 S. S. Hindo, A. M. Mancino, J. J. Braymer, Y. Liu, S. Vivekanandan, A. Ramamoorthy and M. H. Lim, J. Am. Chem. Soc., 2009, 131, 16663-16665.

53 J.-S. Choi, J. J. Braymer, R. P. R. Nanga, A. Ramamoorthy and M. H. Lim, Proc. Natl. Acad. Sci. U. S. A., 2010, 107, 21990-21995.

54 I. Rajaei and S. N. Mirsattari, Polyhedron, 2015, 102, 479-489.

55 P. Anand, A. B. Kunnumakkara, R. A. Newman and B. B. Aggarwal, Mol. Pharmaceutics, 2007, 4, 807-818.

56 Y. Shu, J. Lu, Q.-X. Mao, R.-S. Song, X.-Y. Wang, X.-W. Chen and J.-H. Wang, Carbon, 2017, 114, 324-333. 